\title{
Digital Soil and Landsite Mapping in Forest Management Planning
}

\author{
${ }^{1}$ G. ILLÉS, ${ }^{2} \mathrm{G}$. KOVÁCS, ${ }^{2} \mathrm{~A}$. BIDLÓ and ${ }^{2} \mathrm{~B}$. HEIL \\ ${ }^{1}$ Department of Ecology and Silviculture, Forest Research Institute, Budapest and \\ ${ }^{2}$ Department of Forest Sites, University of West-Hungary, Sopron (Hungary)
}

Under Hungarian conditions, a randomly based comparison between the data of soil sampling plots and data of existing soil descriptions' of the same forested area (e.g. in the case of soil maps or rather soil descriptions in management plans, too) would result in a very poor fit if soil properties were regarded. The reason for this is twofold. On the one hand, forested areas have not always been mapped in a systematic manner. On the other hand, soil properties have not been the first order targets of mapping. They were used as characteristic indicators of taxonomic soil classes. Consequently, the resulting maps contained the soil classes with their typical (or mean) values. In this way, the explored spatial variance of soil attributes within the soil classes and their dependence on the environmental variables were lost (BIDLó et al., 2003). This was partly caused by the lack of suitable tools for extending the data of point samples over the whole study area, including the unvisited sites as well.

At present we have the tools for building and running complex environmental models and they have been developed and are being used widely in ecological researches (Austin, 2002; RECKNAGEL, 2001; LEK \& GuEGAN, 1999; LOREK \& SONNENSCHEIN, 1999; JORGENSEN, 1997). Naturally, this is valid for applied soil sciences, too (SCULL, 2003; LÁSZLÓ \& RAJKAI, 2003).

The sound technological basis is provided mainly by the geographic information systems (GISs) and the sophisticated statistical software solutions, which offer efficient and fast data mining techniques. Coupling these two provides the means of deriving high resolution and reliable soil property and soil class maps or at least towards maps with known error ranges and confidence levels.

The effort for predicting soil properties or soil classes from environmental variables roots in a very simple cause: Preparing accurate soil maps in a traditional way is a very expensive and time consuming activity and the data for the required environmental variables are generally easier to obtain than data on soils. This approach has already been applied in several studies on soil mapping so far (MCBRATNEY et al., 2000; DOBOS et al., 2000, 2002; ODEH et al., 1992; ZHU, 1997; SINOWSKI \& AUSERWALD, 1999).

Correspondence to: GÁBOR ILLÉS, Department of Ecology and Silviculture, Forest Research Institute, H-1023 Budapest, Frankel L. út 42-44. Hungary. E-mail: illesg@erti.hu 
Soil models are based on the concept that there is an existing relationship between soils' properties and the co-existing environmental factors. To express it in short:

$$
S=f(r, g, c, \ldots, t) ; \quad S=f(E)
$$

where: $S=$ the required soil property; $r=$ relief features; $g=$ geography; $c$ = climate; $t=$ time; $E$ = soil forming environmental factors.

This is the common hypothesis of all soil models, but they may differ in which soil attributes and exploratory techniques are used to achieve predictions.

For solving the equation some observations of soil $(S)$ are needed in the field at known locations and functions, using meaningful predictor variables of environment $(E)$ from the soil development's point of view. The predictor variables of " $E$ " are generally represented as raster data layers in a GIS, while the observations of " $S$ ", originating from distinct soil samples, are represented as point data layer in the same GIS (MCBRATNEY et al., 2003).

Up till now, a generalized, widespread and commonly used procedure has not been worked out to set up and approximate the equation above. The reason for this is that most of the studies deal with one or only a few of the possible soil attributes and the methods have different suitability for predicting them in accordance with the set of predictor variables.

\section{Materials and Methods}

The above-described experimental soil mapping approach was applied in three different forest areas: 1. a peat land in Northwest Hungary called the Hanság (ILLÉS et al., 2002, 2003; ILLÉS, 2001); 2. the so-called Széki forest in the hilly bottom region of the Bakony Mountains; and 3. a forest reserve of the Bükk Mountains in Northeast Hungary, called Várhegy (Fig. 1).

\section{Application in a peat land (Hanság)}

The research in the Hanság region aimed to model the soil forming environmental conditions and the occurrence of different soil types in their presence, using fuzzy classification, multivariate regressions (ZHU et al., 1996, 2001; ZHU, 1997; McBratney \& ODEh, 1997) and GIS applications (ZhU, 2000; JANG, 1993). Modelling the soil forming factors and making reliable predictions of the soil attributes were done with the purpose of improving the local forest management. From soil scientific point of view, this region can be represented by a set of organic soils, making the area a unique field for research. First, a detailed GIS database of the Hanság was established, focusing on forestry. A forest stand growth rateweighted random sampling design was applied to collect soil samples from known locations (GPS). Afterwards, a fuzzy classification of soil data and environmental variables was carried out to identify the naturally occurring soil property versus environmental property groups. 


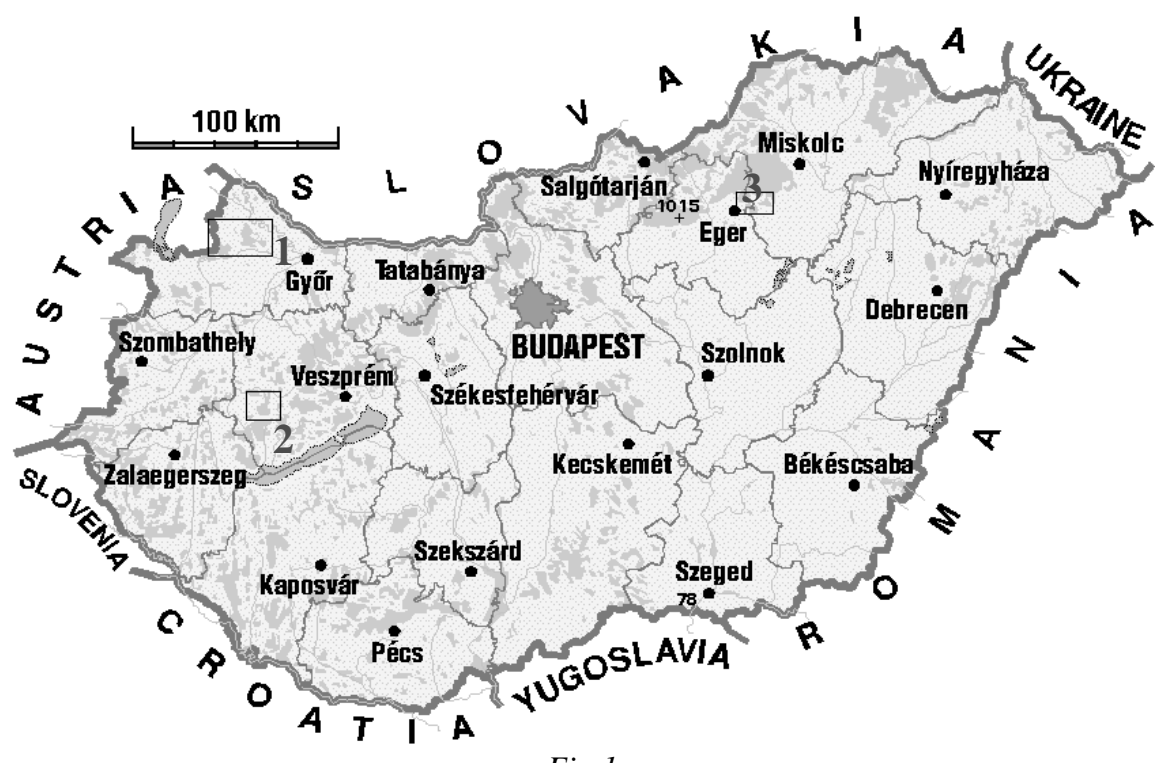

Fig.1

The map of Hungary showing the study areas.

1. Peat land, the Hanság; 2. Széki forest, and 3. Forest reserve, Várhegy.

Finally, a within group, stepwise multivariate regression was used to set up formal relationships between the values of environmental variables (as predictors) and the values of soil attributes (as dependent variables). Running the resulted equations on the raster datasets within the GIS frame it is possible to plot the required soil property maps. The environmental dataset included the following raster maps:

- the digital map of geological formations at $2 \mathrm{~m}$ depth below the surface (SCHAREK, 1991);

- the digital map of the monthly average depth of the groundwater table derived from the measurements of groundwater wells in the study area from 1955 to 2000, data of 540 months (ÉDUVIZIG), and

- the digital topographic map of the area, in a 1:10 000 scale, which was used to generate a digital elevation model (DEM) for the study area. Further maps derived from the DEM were the slope and aspect map and maps of micro-watersheds and their lowest points.

Concerning field observations, we had altogether 96 randomly selected sample plots, which served as the samples for soil property examinations. The data of 74 randomly selected plots provided the base of the soil property model and the remaining plots served as validation points.

The soil data - originating from the sample plots - were uploaded to the GIS database.

The following observations were made at each location: soil profile description; delineation of soil layers; description of the rootable depth, or peat layer thickness, and soil characteristics from the laboratory analyses of soil samples. 
Data processing had two main aspects: grouping the cases based on the soil and environmental parameters and establishing relationships between environmental and soil data.

To avoid the known restrictions of crisp classification methods fuzzy classification (ZADEH, 1965; PODANI, 1997) was applied (using the SYN-TAX 2000 (PODANI, 2000) software). The above-described complex dataset served as the input for fuzzy clustering in order to identify the naturally separating classes and their transitions among environmental variables and soil property variables. Five classes were identified and delineated on the maps. The delineation of classes was followed by the within-class soil property assessment.

Separate sets of environmental variables were found for each class, which are responsible for determining the main soil properties. Therefore, the class-by-class parameter estimation came up with better results than the parameter estimation over the pooled data. The step-forward multiple regression method was used to fit the following general equation:

$$
\begin{array}{r}
\text { SP }=a_{0}+a_{1} *(\text { Elevation })^{a 2}+a_{3} *(\text { Slope })^{a 4}+a_{5} *(\text { Aspect })^{a 6}+a_{7} *(\text { Parent mat. })^{a 8}+ \\
+a_{9} *(\text { Watershed dist. })^{110}+a_{11} *(w)^{a 12}
\end{array}
$$

where:

$S P=$ the assessed soil property;

$a_{0}, a_{1}, a_{3}, a_{5}, a_{7}, a_{9}, a_{11}=$ parameters for the regression;

$a_{2}, a_{4}, a_{6}, a_{8}, a_{10}, a_{12}=$ exponents $1-5$;

Watershed dist. $=$ distance from the lowest point of the watershed in the percentage of the furthest point's distance;

$w=$ the 50-year average distance of groundwater from the surface.

\section{Application in a hilly region (Széki forest) and in a mountainous region (Várhegy)}

In the case of study areas 2 and 3, the aim of the research was to investigate how the relief features affect the values of A horizon thickness, and rootable depth. Different types of brown forest soils and lithomorphic soils occur in the study areas. Systematic sampling designs were applied with a $100 \times 100 \mathrm{~m}$ grid size in the case of the Széki forest (2), and a 50×50 m grid in the case of the Várhegy (3) study area (Fig. 2).

Soil borer sampling provided the requested field values for the assessment on site. During the data processing, the recorded soil parameters and the relief features (altitude, slope, aspect, profile and plan form curvatures) were coupled within a GIS frame. DataFit 8.1 software (OAKDALE ENGINEERING, 2005) was used to derive possible relationships between relief and soil data and to plot local characteristic curves for soil attributes by different relief features. For the regression, first the relief features (such as altitude and curvature) were grouped, then the group-wise average values of soil attributes by relief groups were used. 


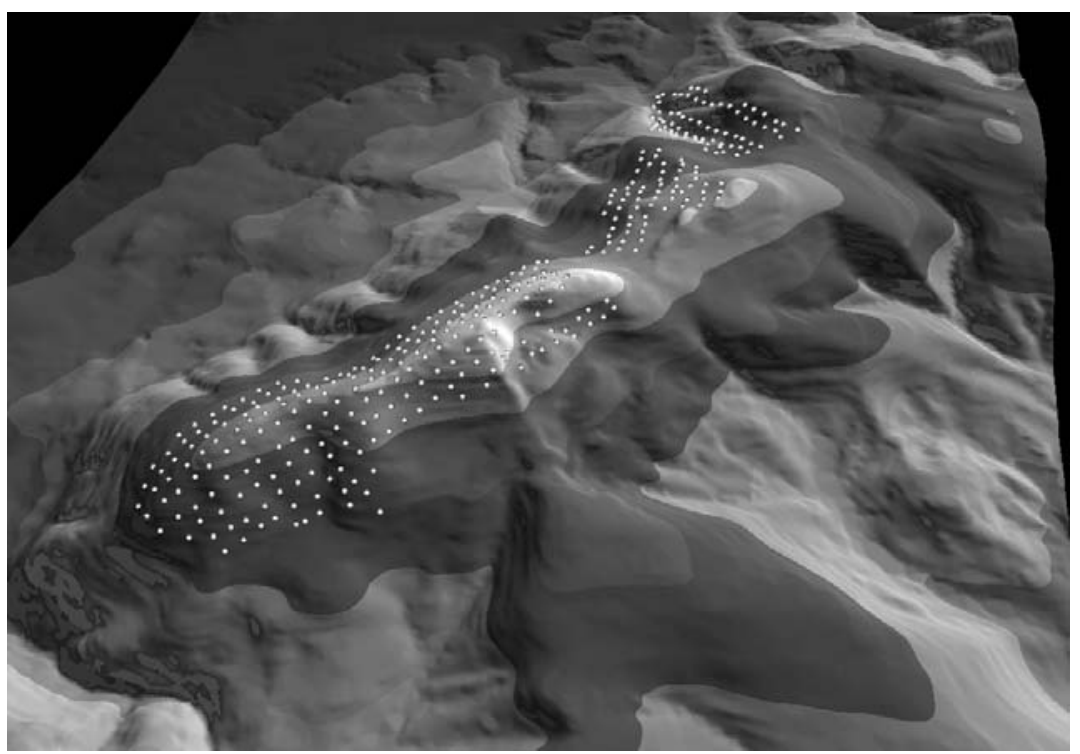

Fig.2

The perspective view of the Várhegy (study area 3) with the sampling plots of a $50 \times 50 \mathrm{~m}$ grid

\section{Results and Discussion}

From the results of the investigation in the Hanság region (study area 1), a map demonstrating the spatial pattern of the rootable depth thickness is presented (Fig. 3). This may be considered as one of the most important soil properties from the forest management point of view. Fig. 4 shows the error distribution of our predictions over the control or validation samples.

Figs. 5 and 6 illustrate preliminary results of the study carried out in the Széki forest (study area 2) and Várhegy region (study area 3).

These preliminary results have already revealed some important facts:

1. There are recognizable relationships between some physical attributes of soil and relief features.

2. The relationship may differ for different relief features.

3 . The character of the relationship is probable to vary from site to site.

In the Hanság study area (Figs. 3 and 4) it was found that the prediction error remained within the average category range of the currently used rootable depth thickness categories for forestry in $60 \%$ of the cases. There is a $30 \%$ chance of missing the range by one category and $10 \%$ to have even greater differences. These error ranges are still considered rather wide, but by increasing the sampling density the proportion of correctly classified areas is probably improvable. 


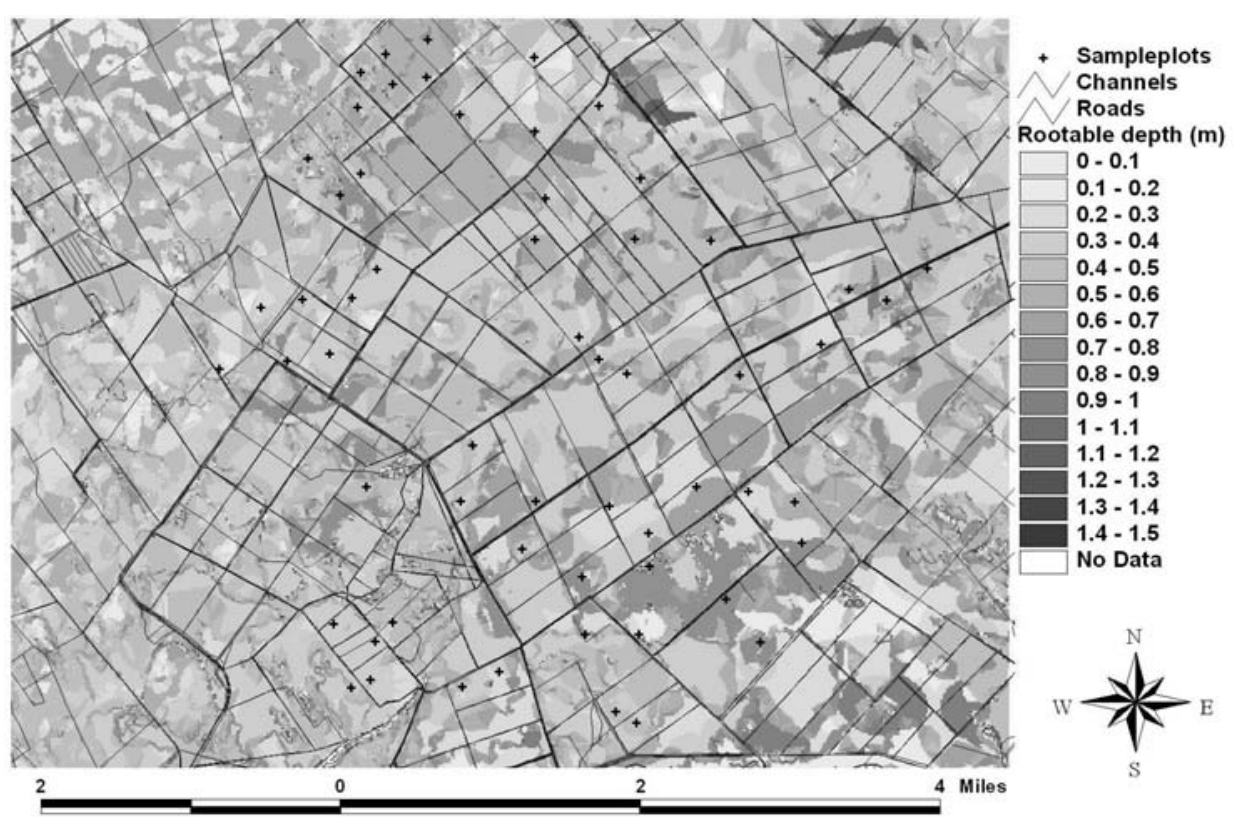

Fig. 3

Map of the predicted rootable depth under study area 1 (The Hanság)

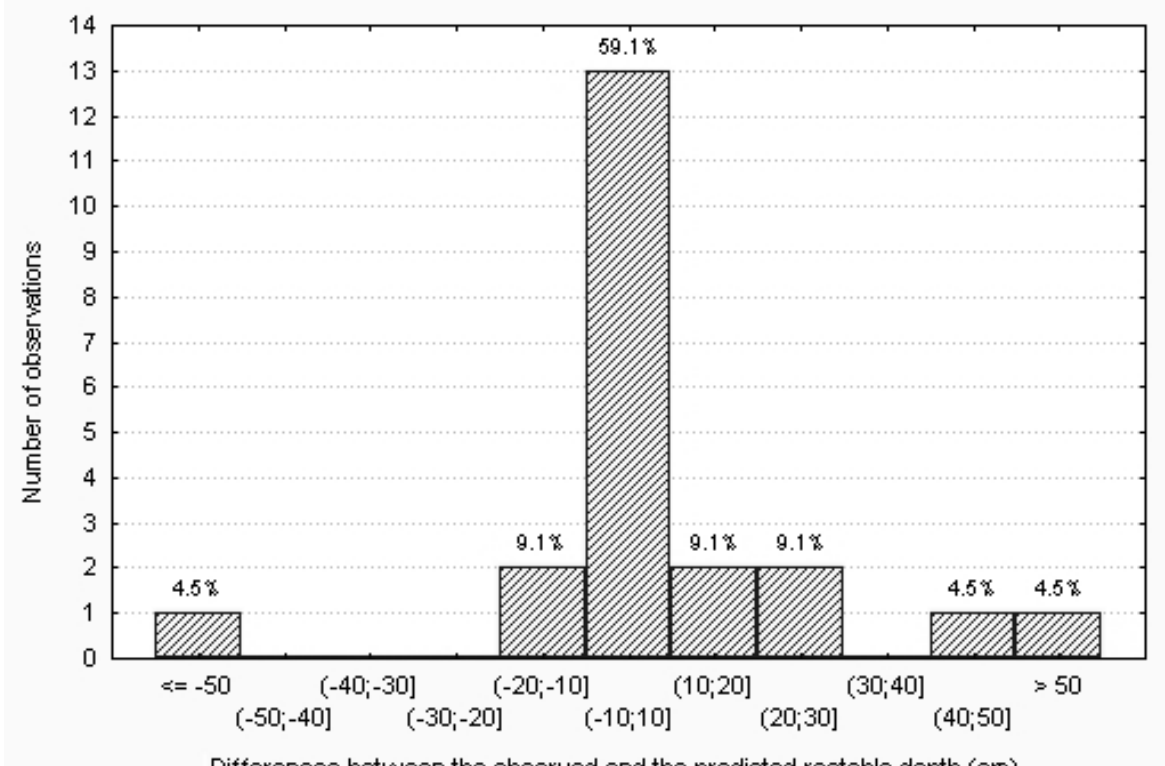

Differences between the observed and the predicted rootable depth (cm)

Fig. 4

The error distribution of predicted values over observed values of the rootable depth (Study area 1, the Hanság) 
Considering the relief features-soil attributes characteristic curves it was found that the relationship may be different at different locations. So, it is hard to imagine curves that are generally accurate and can be used commonly. The run of the curves seem to differ for hilly and mountainous regions, therefore local surveys need to be evaluated separately.

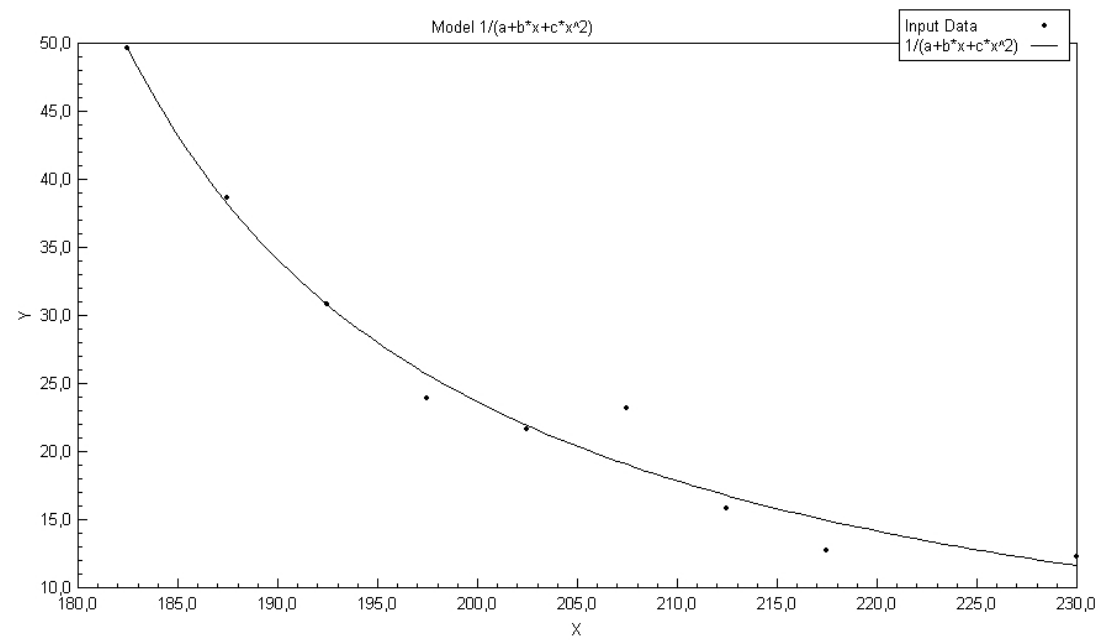

Fig.5

The empirical, local characteristics curve of altitude $(\mathrm{m})(\mathrm{X})$ versus A horizon thickness $(\mathrm{cm})(\mathrm{Y})$ for the Széki forest (study area 2$)\left(\mathrm{R}^{2}=0.97\right)$

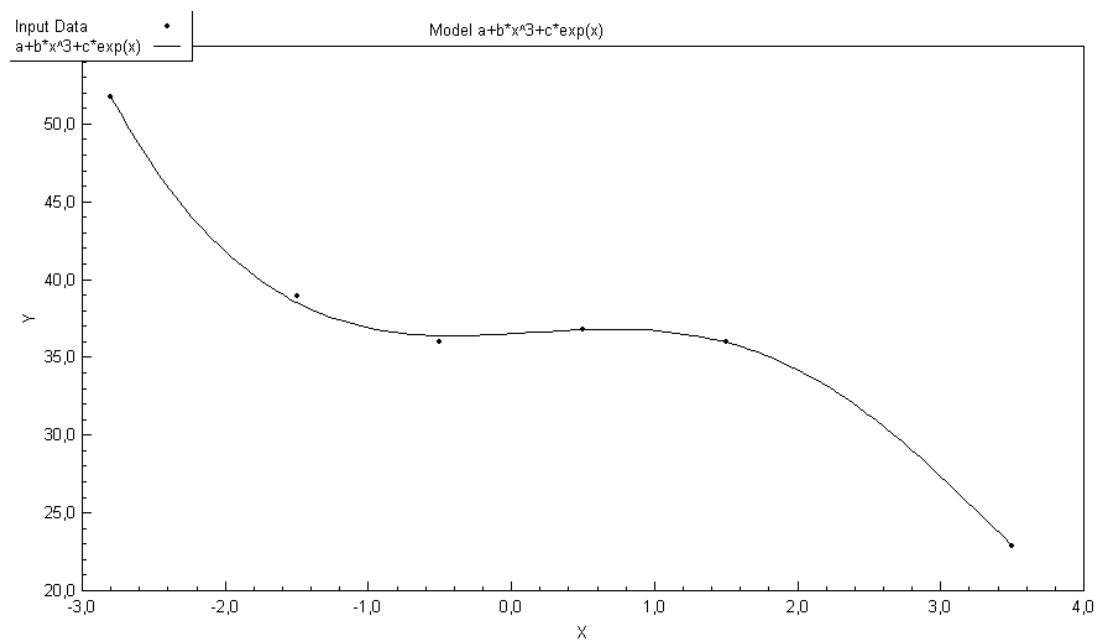

Fig.6

The empirical, local characteristics curve of profile curvature $(1 / 100 \mathrm{~m})(\mathrm{X})$ versus A horizon thickness $(\mathrm{cm})(\mathrm{Y})$ for the Várhegy forest reserve (study area 3) $\left(\mathrm{R}^{2}=0.99\right)$ 
As a consequence of the above-mentioned, it is hard to derive a general set of rules which may be convenient for everyday use in a widespread mapping algorithm. Considering these results, further research activities should continue in two main directions. First, there is a classification problem to handle: to predict the possible soil classes based on the sets of environmental data, having learning and testing samples large enough to derive and validate classifications. This task may be solved by the use of artificial neural networks or classification trees (BEHRENS et al., 2005). The second problem is more regression-like, which includes the method of predicting the within class soil attributes from the spatial model of pedologically meaningful variables on the basis of sampling.

\section{Conclusions}

The GIS frame and spatial statistics enable the building of complex models by taking into consideration as many meaningful environmental variables as possible for task-oriented spatial modelling. Spatial model-based site mapping in turn provides new possibilities for forest management. Digital soil maps with additional layers of environmental variables would be a milestone in forestry-oriented site evaluation. Attempts to model the relationships between soil and its environment hopefully lead to increasing the efficiency of forest management planning. The paper demonstrated some preliminary, but promising results in this respect. New methods, however, require scientific and technological expertise. The basis of digital soil and site maps is the detailed evaluation of environmental and soil attributes. In this way hitherto mismatched information can be combined.

Fields, where further improvements are necessary include the compilation of environmental databases, data mining and predictions, spatial error handling, and development of a stand-alone application.

\section{Summary}

The current methodology of forest site evaluation has some challenging weaknesses, which may greatly influence the efficiency of both forest planning and forest management practice. This fact keeps us searching for new methods to overcome the difficulties. The present paper gives a short overview of our research on GIS based digital soil mapping techniques and their possible application in forestry, offering a powerful tool for forest site evaluation. The paper focuses on four main issues. First, the main weakness in site evaluation, second, methods of digital soil mapping, third, the description of the study areas and mapping procedures, and finally, the possible outcomes and the major directions of further development. 
The present work was supported by the Ministry of Agriculture and Rural Development, and the Forest Reserve Programme of the Ministry of Environment and Water of the Hungarian State.

Key words: soil mapping, site evaluation, spatial modelling, statistics, forestry

\section{References}

Austin, M. P., 2002. Spatial prediction of species distribution: an interface between ecological theory and statistical modelling. Ecological Modelling. 157. 101-118.

BEHRENS, T. et al., 2005. Digital soil mapping using artificial neural networks. J. Plant Nutr. Soil Sci. 168. 1-13.

BIDLÓ, A. et al., 2003. The site classification system of Hungarian forestry sector and its problems. In: Proc. of the Conf. on Land Quality and Landuse Information. (In Hungarian) 115-124. University of Veszprém. Keszthely.

Doвos, E. et al., 2000. Use of combined digital elevation model and satellite radiometric data for regional soil mapping. Geoderma. 97. 367-391.

DoBos, E. et al., 2002. The use of DEM and satellite data for regional scale soil databases. Agrokémia és Talajtan. 51. 263-272.

ILLÉs, G., 2001. Forest research in the North Hanság. (In Hungarian) Journal of Forestry. 136. (2) 46-50.

ILLÉs, G., KovÁCS, G. \& BIDLÓ, A., 2002. The investigation of the site conditions of North-Hanság using GIS tools. (In Hungarian) Proc. of the Forest Research Institute. 90. 99-116.

ILLÉs, G. et al., 2003. Site mapping using GIS tools and fuzzy clustering in wetlands. (In Hungarian) Acta Agraria Kaposváriensis. 7. (3) 45-68.

JANG, J. S. R., 1993. ANFIS - Adaptive-Network-Based Fuzzy Inference System. IEEE Transactions on Systems, Man and Cybernetics. 23. 665-685.

JORGENSEN, S. E., 1997. Ecological modelling by "ecological modelling”. Ecological Modelling. 100. 5-10.

LÁsZLÓ, P. \& RAJKAI, K., 2003. Modelling soil erosion. (In Hungarian) Agrokémia és Talajtan. 52. 427-442.

LEK, S. \& GUEGAN, J. F., 1999. Artificial neural networks as a tool in ecological modelling, an introduction. Ecological Modelling. 120. 65-73.

LOREK, H. \& SONNENSCHEIN, M., 1999. Modelling and simulation software to support individual-based ecological modelling. Ecological Modelling. 115. 199-216.

MCBRATNEY, A. B. \& ODEH, I. O. A., 1997. Application of fuzzy sets in soil science: fuzzy logic, fuzzy measurements and fuzzy decisions. Geoderma. 77. 85-113.

McBratney, A. B., Mendonca Santos, M. L. \& Minasny, B., 2003. On digital soil mapping. Geoderma. 117. 3-52.

McBratNeY, A. B. et al., 2000. An overview of pedometric techniques for use in soil survey. Geoderma. 97. 293-327.

OAKDALE ENGINEERING, 1995-2005. DataFit 8.1 software. 
Odeh, I. O. A., McBratney, A. B. \& Chittleborrough, D. J., 1992. Soil pattern recognition with fuzzy c-means: application to classification and soil-landform interrelationships. Soil Sci. Soc. Am. J. 56. 505-516.

PODANI, J., 1997. Fuzzy classifications. In: Introduction to the Mystery of Biological Multivariate Data Processing. Scientia. Budapest.

PODANI, J., 2001. User’s Manual. Syn-Tax 2000 Software. Budapest.

RECKNAGEL, F., 2001. Applications of machine learning to ecological modelling. Ecological Modelling. 146. 303-310.

SCHAREK, P. (Ed.), 1991. The Geological Map Series of the Little Hungarian Plain Mosonmagyaróvár. (In Hungarian) Hungarian Geological Institute. Budapest.

Scull, P., 2003. Predictive soil mapping: a review. Progress in Physical Geography. 27. 171-197.

SINOWSKI, W. \& AUSERWALD, K., 1999. Using relief parameters in a discriminant analysis to stratify geological areas with different spatial variability of soil properties. Geoderma. 89. 113-128.

ZADEH, L. A., 1965. Fuzzy sets. Inf. Control. 8. 338-353.

ZHU, A. X., 1997. A similarity model for representing soil spatial information. Geoderma. 77. 217-242.

ZHU, A. X., 2000. Mapping soil landscape as spatial continua: the neural network approach. Water Resources Research. 36. 663-677.

ZHU, A. X. et al., 1996. Automated soil inference under fuzzy logic. Ecological Modelling. 90. $123-145$.

ZHU, A. X. et al., 2001. Soil mapping using GIS, expert knowledge and fuzzy logic. Soil Sci. Soc. Am. J. 65. 1463-1472. 